\title{
Nature or nurture, of beide? Onchocerciasis-geassocieerde epilepsie
}

Wat zijn de mogelijke oorzaken van het ziektebeeld van onchocerciasis-geassocieerde epilepsie? Moeten zowel nature als nurture meegenomen worden bij het zoeken naar oorzaken van aandoeningen, mede vanwege de implicaties voor counseling, preventie en behandeling? In deze bijdrage wordt een overzicht gegeven van mogelijke complex-genetische factoren die nog niet of slechts summier zijn onderzocht.

\section{Onchocerciasis: oorzaalk of trigger?}

De term onchocerciasis-geassocieerde epilepsie geeft al aan dat de etiologie en de pathogenetische mechanismen van epilepsie in de beschreven populaties nog steeds niet opgehelderd zijn. In hoeverre is de onchocerca volvulus infestatie de oorzaak van, of slechts een trigger voor de epileptogenese? Zijn er andere factoren in het spel zoals andere parasitaire infestaties, infecties, voedingselementen, voedingstekorten, verontreinigingen, onbekende medicaties of behandelingen? Hoe te verklaren dat pas nu in een deel van de gebieden waarin onchocerca volvulus prevalent is een link met epilepsie wordt vermoed, waar eerder alleen rivierblindheid met zekerheid werd toegeschreven aan deze infestatie? In welke mate zijn andere oorzaken inclusief genetische oorzaken met huidige middelen uitgesloten?

In het wetenschappelijk veld worden deze onzekerheden en onbeantwoorde vragen deels onderkend (Colebunders et al., 202I). De onderzoekers onderscheiden zichzelf regelmatig als believers (in een causaal verband tussen onchocerciasis en epilepsie) en non-believers, waarbij men niet aan de indruk ontkomt dat de believers vooral onderzoek doen om causaliteit te bevestigen en minder of geen aandacht geven aan onderzoek ter mogelijke falsificatie van vermeende causaliteit, toch een erkend onderdeel van het wetenschappelijke proces. Daarbij valt op dat het vóórkomen van tekenen van onchocerca vaak veel uitgebreider is onderzocht onder personen met epilepsie en niet of nauwelijks in personen uit dezelfde populatie maar zonder epilepsie. Bij pathologisch onderzoek van hersenen van patiënten zijn nog nooit tekenen van onchocerca volvulus gevonden en evenmin bij analyse van lege artis lumbaal verkregen liquor cerebrospinalis. Antistoffen tegen leiomodin-I zijn als mogelijk betrokken bij de pathogenese genoemd, maar komen ook voor bij personen zonder epilepsie. Kortom, is het nature, nurture of toch beide?

\section{Genetisch perspectief}

Vanuit genetisch perspectief zijn er een aantal opgeloste enigmatische voorbeelden van nature versus nurture. Kuru, een spongiforme encefalopathie onder bewoners van Nieuw-Guinea, werd aanvankelijk op grond van voorkomen in families met overwegend matrilineaire doorgave gezien als een mogelijk erfelijke late-onset aandoening (Weiner et al., I97I), totdat transmissie van onder andere mens naar mensaap werd aangetoond (Brown, I990). Vervolgens werd een prion eiwit als infectieus agens geïdentificeerd dat met het eten van hersenen (door vooral vrouwen en kinderen) van geïnfecteerde mensen werd overgedragen en gekenmerkt wordt door een lange incubatietijd van gemiddeld tien tot dertien jaar met uiterste tot 50 jaar (Liberski et al., 2019). Inmiddels heeft zich in de bevolkingsgroep van overlevenden vermoedelijk door het klassieke Darwiniaanse mechanisme van mutatie en selectie een nieuwe variant $\left(\mathrm{G}_{12} 7 \mathrm{~V}\right)$ van het PRNP gen gemanifesteerd die in relatief korte tijd van circa tien generaties weerstand in de populatie tegen deze infectie heeft gevormd (Mead et al., 2009). Het was dus niet erfelijk maar infectieus, terwijl erfelijkheid wel weer een rol ging spelen bij de ontwikkeling van weerstand in de populatie.

Kinkhoest encefalopathie is een diagnose die tot rond het jaar 2000 nog regelmatig werd gesteld wanneer een kind na een van de vroege DKTP-vaccinatie(s) een epileptische encephalopathie ontwikkelde, en waarvoor in sommige landen de jure besloten werd tot hoge bedragen aan schadevergoeding wegens vermeend oorzakelijk verband. Thans weten we dat het klinisch beeld veroorzaakt wordt door 
mutaties in vooral het $\mathrm{SCN} 1 \mathrm{~A}$ waarbij de koorts die optreedt na een vaccinatie of een infectieziekte de eerste epileptische aanval kan uitlokken, maar niet de oorzaak van het klinisch verloop is (Verbeek, 2015). Hier was het dus niet exogeen maar endogeen/genetisch als oorzaak, met een bijrol voor exogeen als trigger voor het eerste symptoom, zoals lichtflitsen een trigger kunnen zijn bij lichtflitsgevoelige epilepsie.

Perceptief slechthorendheid werd in onder andere China en Mongolië gezien als complicatie van behandeling met aminoglygosiden als streptomycine, maar binnen families bleek het patroon van overerving van de slechthorendheid sterk te wijzen op mitochondriële overerving (Hu et al., I99I; Pandya et al., I997). Nader onderzoek toonde een mutatie in een van de mitochondriële genen die alleen voorkwam bij de familieleden die met streptomycine waren behandeld èn slechthorend waren geworden, terwijl de mutatie niet werd gevonden bij familieleden die ondanks de behandeling hun normale gehoor hadden behouden (Gardner et al., 1997). Hier gaat het dus om een combinatie van genetisch bepaalde gevoeligheid die pas door een exogeen agens tot uitdrukking kwam in een ernstige bijwerking, een klassiek voorbeeld van farmacogenetica van bijwerkingen.

Periventriculaire calcificaties in het brein werden in het verleden soms toegeschreven aan een congenitale infestatie met de parasiet Toxoplasma Gondii, terwijl later uit klinisch en moleculair genetisch onderzoek bleek dat het om tubereuze sclerose ging.

\section{Terug naar Tanzania}

In Mahenge, Tanzania, hebben we enkele volwassen patiënten met epilepsie gezien die tevens huidverschijnselen van onchocerca hadden. De als meest kenmerkend gepresenteerde patiënt had een ernstige intellectuele handicap, epilepsie, mogelijk nodding syndroom en huidkenmerken van onchocerca. Maar de associatie vormt geen bewijs voor causaliteit. Had ik dezelfde patiënt met de combinatie van epilepsie en ernstige psychomotore, intellectuele beperking in Nederland gezien, dan zou allereerst trio WES en SNParray onderzoek zijn ingezet met een kans van meer dan $50 \%$ om een genetische oorzaak te vinden. Het zoveel mogelijk uitsluiten van genetische oorzaken vergroot ook de kans om met analytisch epidemiologisch onderzoek andere mogelijke oorzaken in de overige patiënten met epilepsie te identificeren, inclusief de rol van onchocerca volvulus infestatie.

Met genetisch onderzoek kan ook de hele infestatie-keten van de vector black fly (Simulium spp.) - Onchocerca volvulus Wolbachia - Homo sapiens in kaart worden gebracht om te zoeken naar mogelijk additionele causale factoren en, indien bevestigd, aangrijpingspunten voor behandeling. Denk daarbij met name aan genetische variaties in elk van de vier organismen die regionale of tijdsgebonden verschillen zouden kunnen verklaren, zowel wat optreden van epilepsie als reactie op behandeling betreft. Bijzondere aandacht verdient daarbij genetische analyse van tot nu toe verwaarloosde Wolbachia, een bacteriële endosymbiont van Onchocerca volvulus zonder welke deze worm ten dode is opgeschreven. Elk onchocerca cytoplasma bevat vele exemplaren van deze endosymbiont en de vergelijking met de mitochondriën bij de mens, evolutionair gezien eveneens een bacteriële endosymbiont van eencellige oerorganismen, dringt zich op. De behandeling van onchocerca is er deels op geënt, namelijk door middel van doxycycline dat via uitschakeling van Wolbachia leidt tot remming van onchocerca in verschillende stadia van ontwikkeling en fertiliteit. Wellicht dat genetische variatie en selectiemechanismen van Wolbachia eveneens een belangrijke pathogenetische rol spelen (Choi et al., 2016), en zouden kunnen bijdragen aan regionale en tijdsgebonden verschillen in onchocerca infestatie, reactie op behandeling, en optreden van epilepsie.

Ook is de mogelijkheid van een auto-immuun mechanisme van onchocerca-geassocieerde epilepsie geopperd. Een onchocerca infestatie zou door kruisreactiviteit kunnen leiden tot auto-immuun antistoffen tegen leiomodin-I dat gecodeerd wordt door het gen LMOD1 en een functie heeft bij actine- en tropomyosine binding. Echter, niet alle patiënten met bijvoorbeeld nodding syndroom hebben deze antistoffen, terwijl deze antistoffen wel in de algemene populatie worden gevonden en mogelijk ook betrokken zijn bij auto-immuun schildklieraandoeningen. Recent werd gevonden dat leimodin-I weliswaar overal in het brein tot expressie komt, maar dat het slechts gedurende korte tijd ook op de celmembraan van nieuw-gevormde neuronen verschijnt en dan een tijdelijk aangrijpingspunt vormt voor een toxische werking van leiomodin-I antilichamen (Nauen et al., 2020). Dit wordt geopperd als een mogelijke verklaring waarom het ontstaan van epilepsie beperkt is tot de kinderleeftijd en zich niet uitstrekt tot volwassenen, terwijl het niet optreden van epilepsie op de kleuterleeftijd dan weer hypothetisch wordt toegeschreven aan verminderde blootstelling aan de vector en daarmee aan onchocerca volvulus. Wederom blijft hiermee onzeker of leiomodin-I auto-immuun antilichamen wel of geen rol spelen als oorzaak of mechanisme in de pathogenese van bepaalde vormen van epilepsie in Onchocerca volvulus prevalente gebieden.

\section{Conclusie}

Op grond van deze korte kennismaking met onchocerciasis-geassocieerde-epilepsie kom ik tot de volgende conclu- 
sie: Prospectief cohortonderzoek met langdurige follow-up van alle patiënten met epilepsie in onchocerca volvulus prevalente gebieden is een dringende noodzaak om al de hiervoor genoemde aspecten integraal te onderzoeken. Dat vergt veel expertise en uitrusting, flinke investeringen in de lokale gezondheidszorg, internationale samenwerking, alsmede nadere klinische, radiologische, immunologische, epidemiologische, en moleculaire scholing van onze collegae in de betreffende gebieden.

\section{Referenties}

Brown (I990) Transmissible Spongiform Encephalopathies in Humans: Kuru, Creutzfeldt-Jakob Disease and Gerstmann-Straussler-Scheinker Disease. Can J Vet Res I990;54:38-4I.

Choi YJ, Tyagi R, McNulty SN, et al (20I6) Genomic diversity in Onchocerca volvulus and its Wolbachia endosymbiont. Nat Microbiol 20I6;2:16207.

Colebunders R, Njamnshi AK, Menon S et al (202I) Onchocerca volvulus and epilepsy: A comprehensive review using the Bradford Hill criteria for causation. PLoS Negl Trop Dis 2021; I5(I):eooo8965.

Gardner JC, Goliath R, Viljoen D, et al (1997) Familial streptomycin ototoxicity in a South African family: a mitochondrial disorder. J Med Genet 1997;34:904-906. Hu DN, Qiu WQ, WU BT, et al (I99I) Genetic aspects of antibiotic induced deafness: mitochondrial inheritance. J Med Genet I99I;28:79-83.
Liberski PP, Gajos A, Sikorska B et al (20rg) Kuru, the First Human Prion Disease. Viruses 2019;II(3):232. Mead S, Whitfield J, Poulter M, et al (2009) A Novel Protective Prion Protein Variant that Colocalizes with Kuru Exposure. N Engl J Med 2009;36r:2056-2065.

Nauen DW, Haffnewr MC, Kim J, et al (2020) Putative Autoantigen Leiomodin-I Is Expressed in the Human Brain and in the Membrane Fraction of Newly Formed Neurons. Pathogens 2020;9:1036.

Pandya A, Xia X, Radnaabazar J, et al (1997) Mutation in the mitochondrial I2S rRNA gene in two families from Mongolia with matrilineal aminoglycoside ototoxicity. J Med Genet I997;34:I69-I72.

Verbeek, NE (2015) SCN1A-related Dravet syndrome.

Vaccinations and seizure precipitants in disease course and diagnosis. Academic PhD Thesis, University Medical Center Utrecht/Utrecht University. https:// dspace.library.uu.nl/handle/I874/3228Ir.

Weiner LP, Johnson RT (I97I) Slow viral infections of the nervous system and genetic disease. Birth DefOrig Art Series I971;7(I):72-77.

\section{Epilepsie en risico's}

Zeventig procent van de mensen met epilepsie wordt aanvalsvrij. Er zijn dus ook mensen die ondanks medicatie of een andere behandeling nog aanvallen hebben. Die aanvallen kunnen in sommige gevallen risico's met zich meebrengen. Zoals bij de meeste aandoeningen vragen mensen zich af of epilepsie ook levensbedreigend kan zijn. Het antwoord op deze vraag vindt $u$ in de folder 'Epilepsie en risico's'.

Vraagt u de folder aan via e-mail info@epilepsiefonds.nl of telefoon 0306344063 . Het is niet de bedoeling deze folder uit te delen aan patiënten zonder begeleidend gesprek.

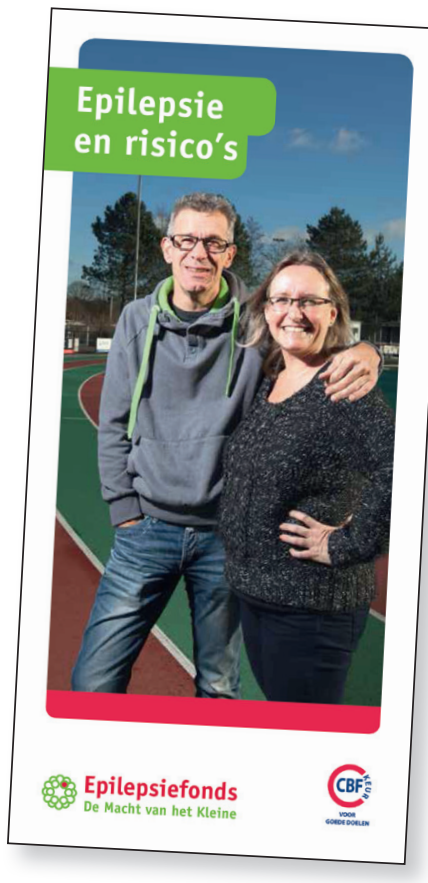

